\title{
NMDARs Adapt to Neurotoxic HIV Protein Tat Downstream of a GluN2A-Ubiquitin Ligase Signaling Pathway
}

\author{
Matthew V. Green and $\$ Stanley A. Thayer \\ Department of Pharmacology and Graduate Program in Neuroscience, University of Minnesota Medical School, Minneapolis, Minnesota 55455
}

HIV-associated neurocognitive disorder (HAND) affects approximately half of HIV-infected patients. Infected non-neuronal cells release neurotoxic factors such as the viral protein transactivator of transcription (Tat) that potentiate NMDAR function. NMDARs regulate synaptic changes observed after exposure to HIV proteins, which may underlie cognitive impairment in HAND patients. Here, we used patch-clamp recording to measure NMDAR-mediated currents in rat hippocampal cultures after exposure to Tat. Tat (4-16 h) potentiated NMDA-evoked whole-cell current and increased the NMDAR:AMPAR ratio of evoked EPSCs. Potentiated currents adapted back to baseline amplitudes after $24 \mathrm{~h}$ of exposure to Tat. Pharmacological inhibition of GluN2A-containing NMDARs prevented adaptation, but inhibition of GluN2B-containing NMDARs did not. Pharmacological and genetic approaches determined that potentiated NMDARs activated the kinase Akt, which then activated the E3 ubiquitin ligase Mdm2. Inhibition of protein synthesis prevented adaptation, suggesting that Mdm2 altered gene expression, possibly through its well known target p53. Expression of GFP-tagged GluN1 subunits resulted in fluorescent puncta that colocalized with synaptic markers. Tat $(24 \mathrm{~h})$ caused an Mdm2-dependent loss of NMDAR puncta on a timescale similar to adaption of NMDAR function. Activation of the Mdm2 pathway degrades PSD-95, a scaffolding protein that clusters NMDARs at the synapse and enhances their function. Adaptation to the continued presence of excitotoxins that potentiate NMDARs such as HIV Tat may protect from excessive NMDAR activation while also contributing to the synaptic loss that correlates with cognitive decline in HAND.

Key words: Akt; GluN2A; GluN2B; HIV Tat; MDM2; NMDAR

Significance Statement

Synaptodendritic damage correlates with cognitive decline in HIV-associated neurocognitive disorder (HAND). In a cell culture model, we show that the HIV protein transactivator of transcription (Tat) initially potentiates NMDARs that then adapt to the presence of the toxin. Adaptation of NMDAR function was mediated by a GluN2A/Akt/Mdm2 pathway not previously linked to neuroinflammatory disorders such as HAND. Activation of this pathway caused a loss of synaptic NMDAR clusters. Decreased NMDAR function may result from a homeostatic response gone awry and underlie impaired synaptic function in HAND.

\section{Introduction}

HIV infects $>36$ million people worldwide and almost half of these patients are estimated to have HIV-associated neurocognitive disorder (HAND) (Heaton et al., 2011; Saylor et al., 2016). The risk of CNS complications is correlated with the presence of viral RNA in the CSF (Hammond et al., 2014). HAND symptoms range from severe dementia to impairments only observed upon

\footnotetext{
Received Sept. 22, 2016; revised 0ct. 26, 2016; accepted 0ct. 31, 2016.

Author contributions: M.V.G. and S.A.T. designed research; M.V.G. performed research; M.V.G. and S.A.T. analyzed data; M.V.G. and S.A.T. wrote the paper.

This work was supported by the National Institutes of Health (National Institute on Drug Abuse Grant DA07304 to S.A.T. and Training Grant T32DA07234 to M.V.G.).

The authors declare no competing financial interests.

Correspondence should be addressed to S.A. Thayer, Department of Pharmacology, University of Minnesota Medical School, 6-120 Jackson Hall, 321 Church Street S.E., Minneapolis, MN 55455. E-mail: sathayer@umn.edu. DOI:10.1523/JNEUROSCI.2980-16.2016

Copyright $\odot 2016$ the authors $\quad 0270-6474 / 16 / 3612640-10 \$ 15.00 / 0$
}

clinical testing. The severity of cognitive impairment correlates with synaptic loss in HAND, as it does in many neurodegenerative diseases (Ellis et al., 2007). Despite the success of combined antiretroviral therapy (cART) at suppressing viral replication, HAND remains prevalent, in part because of the increased lifespan of HIV-infected patients (Saylor et al., 2016). Unfortunately, there is no treatment for the ever-growing population of people living with HAND.

HIV neurotoxicity occurs via an indirect mechanism. The virus productively infects non-neuronal cells, principally microglia, that release neurotoxic factors such as the viral protein transactivator of transcription (Tat). Tat is a potent neurotoxin in vitro, eliciting neuronal death (Eugenin et al., 2007) and producing synaptodendritic damage (Kim et al., 2008). Intrahippocampal injection or CNS expression of Tat impairs cognitive function (Fitting et al., 2006, 2013; Carey et al., 2012). Tat is present in the CSF of patients virologically controlled on cART 
(Johnson et al., 2013). Antibodies against Tat are thought to be neuroprotective because antibody titers negatively correlate with cognitive impairment in HIV patients (Bachani et al., 2013). Furthermore, once the virus has integrated into the cell's genome, Tat production is not significantly attenuated by cART (Johnson et al., 2013).

Excessive activation of NMDARs is a mechanism common to many neurodegenerative disorders and the neuroinflammatory factors implicated in HAND are no exception. The HIV envelope protein gp120 (Viviani et al., 2006), Tat (Haughey et al., 2001; Krogh et al., 2014), and the inflammatory cytokines TNF- $\alpha$ (Habbas et al., 2015) and IL-1 $\beta$ (Viviani et al., 2003) all increase NMDAR function. In hippocampal cultures, Tat potentiated NMDAR receptor activity through Src-mediated tyrosine phosphorylation (Haughey et al., 2001; Krogh et al., 2014). Interestingly, the culture adapted to increased NMDAR activity by reducing the number of excitatory synapses (Kim et al., 2008) and increasing the number of inhibitory synapses (Hargus and Thayer, 2013), suggesting that synaptic changes in neuroinflammatory conditions such as HAND are part of a coping mechanism. NMDA-evoked increases in $\left[\mathrm{Ca}^{2+}\right]_{\mathrm{i}}$ also adapted after Tat-induced potentiation, consistent with the idea that a homeostatic reduction in $\mathrm{Ca}^{2+}$ influx might drive the adaptive response (Krogh et al., 2015).

Here, we measured synaptic and NMDA evoked currents and show that they initially potentiate, then adapt in the maintained presence of Tat. Inhibition of GluN2A-containing NMDARs, but not GluN2B-containing NMDARs, prevented adaptation, but both NMDAR subtypes were similarly potentiated and adapted. Inhibition of the E3 ubiquitin ligase mouse double minute 2 $(\mathrm{Mdm} 2)$ or the kinase Akt prevented adaptation, suggesting that these signaling processes regulate adaptation downstream of GluN2A-containing NMDARs. Finally, we show that clusters of GFP-tagged NMDARs were lost over the same timescale that NMDAR-mediated currents returned to baseline. This is the first report of a GluN2A-Akt-Mdm2 pathway, leading to a downregulation of NMDAR activity and could be a common adaptive response to neuroinflammatory conditions.

\section{Materials and Methods}

Materials. Materials were obtained from the following sources: a plasmid that encoded NR1 fused to GFP (pCI-EGFP-NR1 wt) was generated in Robert Malinow's laboratory and obtained from Addgene. The alternative reading frame polypeptide (ARF) expression vector (pcDNA3-mycARF) was kindly provided by Yanping Zhang (Zhang et al., 1998). The expression vector for tdTomato behind the synapsin promoter was generated by excising tdTomato from pLVX-tdTomato-N1 (ClontechTakara Bio) and inserting it into the pSyn backbone of pSyn PSD-95-GFP kindly provided by Kirill Martemyanov (Scripps Research Institute). 6-Cyano-7-nitroquinoxaline-2,3-dione disodium (CNQX), ifenprodil, bicuculline methiodide, tetrodotoxin (TTX), and anisomycin were from Tocris Bioscience. MK-2206 was from Cayman Chemical. Dulbecco's modified Eagle medium (DMEM), fetal bovine serum, and horse serum were from Invitrogen. Rat receptor associated protein (RAP) was from Fitzgerald Industries International. Nutlin-3, NVP-AAM007, and all other reagents were from Sigma-Aldrich. HIV-1 Tat (Clade B, recombinant) was obtained through the National Institutes of Health (NIH) AIDS Research and Reference Reagent Program, Division of AIDS, National Institute of Allergy and Infectious Diseases, NIH from Dr. John Brady.

Cell culture. Rat hippocampal neurons were grown in primary culture as described previously (Waataja et al., 2008). Briefly, both male and female fetuses were removed on day 17 from maternal rats killed with $\mathrm{CO}_{2}$. Hippocampi were dissected and placed in $\mathrm{Ca}^{2+}$ and $\mathrm{Mg}^{2+}$-free HEPES-buffered Hank's salt solution (HHSS), pH 7.45. HHSS was com- posed of the following (in mM): 20 HEPES, $137 \mathrm{NaCl}, 1.3 \mathrm{CaCl}_{2}, 0.4$ $\mathrm{MgSO}_{4}, 0.5 \mathrm{MgCl}_{2}, 5.0 \mathrm{KCl}, 0.4 \mathrm{KH}_{2} \mathrm{PO}_{4}, 0.6 \mathrm{Na}_{2} \mathrm{HPO}_{4}, 3.0 \mathrm{NaHCO}_{3}$, and 5 glucose. Cells were dissociated by trituration through flamenarrowed Pasteur pipettes of decreasing aperture and resuspended in DMEM without glutamine supplemented with $10 \%$ fetal bovine serum and penicillin/streptomycin (100 U/ml and $100 \mu \mathrm{g} / \mathrm{ml}$, respectively). Dissociated cells were then plated at a density of 70,000-80,000 cells per dish onto either a $35 \mathrm{~mm}$ Petri dish with a $10 \mathrm{~mm}$ coverglass bottom (MatTek) or a $25 \mathrm{~mm}$-round cover glass (\#1) precoated with matrigel $(150 \mu \mathrm{l}, 0.2 \mathrm{mg} / \mathrm{ml})$. Neurons were grown in a humidified atmosphere of $10 \% \mathrm{CO}_{2}$ and $90 \%$ air, $\mathrm{pH} 7.4$, at $37^{\circ} \mathrm{C}$, and fed on days 1 and 7 by exchange of $75 \%$ of the medium with DMEM supplemented with $10 \%$ horse serum and penicillin/streptomycin. Cells used in these experiments were cultured without mitotic inhibitors for a minimum of $12 \mathrm{~d}$, resulting in a mixed glial-neuronal culture. Immunocytochemistry experiments demonstrated that these cultures were composed of $18 \pm 2 \%$ neurons, $70 \pm 3 \%$ astrocytes, and $9 \pm 3 \%$ microglia (Kim et al., 2011). Cells used for experiments were grown for 12-15 d in vitro (DIV).

Electrophysiology. Electrodes were pulled using a horizontal micropipette puller (P-87; Sutter Instruments) from glass capillaries (Narishige). Pipette resistance was 3-5 $\mathrm{M} \Omega$ when filled with the following intracellular recording solution (in mM): $145 \mathrm{~K}$-gluconate, 10 HEPES, 5 MgATP, $0.5 \mathrm{NaGTP}$, and 10 BAPTA, pH adjusted to 7.2 with $\mathrm{KOH}$, osmolarity $310 \mathrm{mOsm}$. Recordings were performed with the following extracellular solution (in mM): $125 \mathrm{NaCl}, 2 \mathrm{KCl}, 2 \mathrm{CaCl}, 25 \mathrm{HEPES}, 30$ glucose, and 2 $\mathrm{MgCl}$ ( $\mathrm{MgCl}$ was omitted for $\mathrm{Mg}$-free solutions), $\mathrm{pH}$ adjusted to 7.35 with $\mathrm{NaOH}$, osmolarity $315 \mathrm{mOsm}$. Whole-cell voltages were amplified with an AxoPatch 200B (Molecular Devices), low-pass filtered at $2 \mathrm{kHz}$, and digitized at $10 \mathrm{kHz}$ with a Digidata $1322 \mathrm{~A}$ digitizer and pClamp software (Molecular Devices). Cells with series resistance over $25 \mathrm{M} \Omega$ were excluded from analysis. Whole-cell capacitance was measured after break-in.

To record NMDA-evoked currents, cells were voltage clamped at $-60 \mathrm{mV}$ and washed for $60 \mathrm{~s}$ in $\mathrm{Mg}^{2+}$-free solution containing $3 \mu \mathrm{M}$ CNQX, 100 nм TTX, $15 \mu \mathrm{m}$ glycine, and $10 \mu \mathrm{m}$ bicuculline. Then, $10 \mu \mathrm{M}$ NMDA was applied by superfusion. The steady-state current amplitude was determined from a $10 \mathrm{~s}$ average after $30 \mathrm{~s}$ of exposure to NMDA. All cells used in this study reached a steady-state response by $30 \mathrm{~s}$. A $30 \mathrm{~s}$ average baseline measurement was taken before the addition of NMDA and subtracted from the steady-state current amplitude.

To record synaptically evoked currents, cells were either voltage clamped at $-70 \mathrm{mV}$ (for AMPA EPSCs) or $+40 \mathrm{mV}$ (for combined AMPA and NMDA EPSCs). AMPA EPSCs were evoked every $2 \mathrm{~s}$ with a $15 \mathrm{~V}$ stimulus ( $1 \mathrm{~ms}$ duration) using a concentric bipolar electrode placed near a presynaptic cell. Combined AMPA and NMDA EPSCs were elicited with the same presynaptic stimulation at a frequency of $0.2 \mathrm{~Hz}$. The amplitude of the AMPA response was measured at the peak of the AMPA EPSC. The amplitude of the NMDA response was measured as a $5 \mathrm{~ms}$ average $30 \mathrm{~ms}$ after the peak of the combined AMPA and NMDA EPSC, a time point when the AMPA EPSC had deactivated. Data were analyzed using ClampFit (Molecular Devices) and Origin software (OriginLab).

Transfection. Rat hippocampal neurons were transfected on DIV 9-11 using a previously described protocol (Hargus and Thayer, 2013). Briefly, hippocampal cultures were incubated for 20 min in DMEM supplemented with $1 \mathrm{~mm}$ kynurenic acid, $10 \mathrm{~mm} \mathrm{MgCl}_{2}$, and 5 mм HEPES to reduce neurotoxicity. A DNA/calcium phosphate precipitate containing $1 \mu \mathrm{g}$ of total plasmid DNA per well was prepared, allowed to form for 60 $\mathrm{min}$ at room temperature, and added to the culture. After a $60 \mathrm{~min}$ incubation period, cells were washed once with DMEM supplemented with $\mathrm{MgCl}_{2}$ and HEPES and then returned to conditioned medium that had been saved at the beginning of the procedure. Transfected neurons were used for Experiments 48-96 h after transfection as stated for each experiment.

Confocal microscopy and image processing. Cells were visualized with an inverted laser scanning confocal microscope (Nikon A1) using a $60 \times$ (1.4 numerical aperture) oil-immersion objective. GFP was excited at $488 \mathrm{~nm}$ and emission collected from 500 to $550 \mathrm{~nm}$. TdTomato was excited at $561 \mathrm{~nm}$ and emission collected from 570 to $620 \mathrm{~nm}$. The same cell was imaged before and after a $24 \mathrm{~h}$ treatment period by saving the 

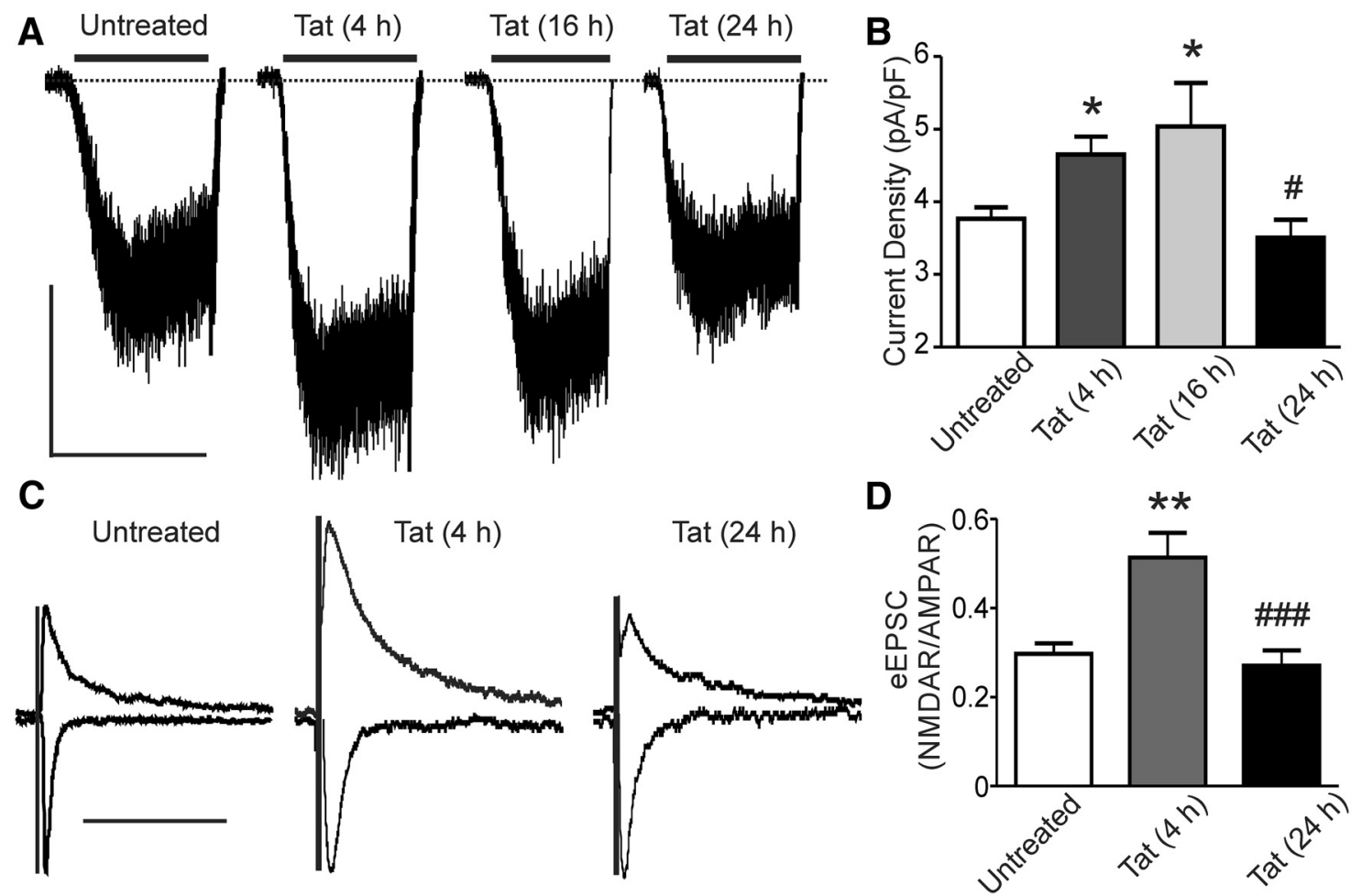

Figure 1. HIV-1 Tat potentiates NMDAR-mediated currents that adapt to baseline during $24 \mathrm{~h}$ of exposure. $A$, Representative traces showing NMDA-evoked steady-state whole-cell currents from neurons voltage clamped at $-60 \mathrm{mV}$ after being treated for $0,4,16$, or $24 \mathrm{~h}$ with Tat. NMDA $(10 \mu \mathrm{m})$ was applied as indicated by the horizontal bars. Scale bar, $100 \mathrm{pA}, 60 \mathrm{~s}$. B, Bar graph summarizing the effects of $0,4,16$, and $24 \mathrm{~h}$ treatment with Tat on the NMDA-evoked steady-state whole-cell current normalized to whole-cell capacitance. Data are mean \pm SEM ( $n \geq 4$ for all groups). ${ }^{*} p<$ 0.05 relative to untreated, $\# p<0.05$ relative to 4 and $16 \mathrm{~h}$ Tat-treated groups (one-way ANOVA with Tukey's post hoc test). C, Representative traces showing evoked EPSCs from neurons voltage clamped at $-70 \mathrm{mV}$ (AMPAR) and $+40 \mathrm{mV}$ ( $+30 \mathrm{~ms}$ taken as NMDAR EPSC) from cells treated for 0,4 , or $24 \mathrm{~h}$ with Tat. The presynaptic neuron was stimulated using a bipolar concentric electrode positioned near the soma. Traces were normalized to AMPAR currents. Scale bar, $100 \mathrm{~ms}$. D, Bar graph summarizing the effects of Tat treatment for 0, 4, and $24 \mathrm{~h}$ on the NMDAR:AMPAR ratio of evoked EPSCS. Data are shown as mean \pm SEM ( $n \geq 6$ for all groups). ${ }^{* *} p<0.01$ relative to untreated, \#\#\#p $<0.001$ relative to Tat-treated ( $4 \mathrm{~h}$ ) (one-way ANOVA with Tukey's post hoc test).

coordinates of a computer-controlled stage. Multiple optical sections spanning $8 \mu \mathrm{m}$ in the $z$-dimension were collected ( $1 \mu \mathrm{m}$ steps) and these optical sections were combined through the $z$-axis into a maximum $z$ projection. An algorithm using MetaMorph 6.2 image processing software was used to count NR1-GFP puncta (Waataja et al., 2008). A threshold set 0.25 times $1 \mathrm{SD}$ above the image mean was applied to the tdTomato image. This created a 1 bit image, which was used as a mask via a logical AND function with the GFP maximum $z$-projection. A top-hat filter ( 80 pixels) was applied to the masked NR1-GFP image. A threshold set 1.5 SDs above the mean intensity inside the mask was then applied to the contrast enhanced image. Structures between 12 and 80 pixels $\left(\sim 0.09-0.65 \mu \mathrm{m}^{2}\right)$ were counted as PSDs. The structures were then dilated and superimposed on the tdTomato maximum $z$-projection for visualization.

Immunocytochemistry. Hippocampal cultures were prepared as described above and maintained for at least $12 \mathrm{~d}$ in culture. Cells were transfected with pCI-EGFP-NR1 wt only, as described above. Seventytwo hours after transfection, cells were washed with PBS and then fixed with $100 \%$ methanol for $10 \mathrm{~min}$ at $-20^{\circ} \mathrm{C}$. The cells were washed with PBS and then blocked in 10\% BSA in PBS (blocking buffer) for 30 min. Cells were then incubated with a rabbit anti-GFP antibody (A11122, 1:500; Thermo Fisher Scientific) and a mouse anti-PSD-95 antibody (sc32291, 1:200; Santa Cruz Biotechnology) in blocking buffer for $16 \mathrm{~h}$ at $4^{\circ} \mathrm{C}$. Cells were washed with PBS and labeled with fluorescein isothiocyanate (FITC) goat anti-rabbit antibody (F2765, 1:500; Thermo Fisher Scientific) and tetramethylrhodamine (TRITC)-conjugated goat antimouse antibody (1:500; Millipore) in blocking buffer for $1 \mathrm{~h}$ at room temperature. Cells were imaged using confocal microscopy as described above. TRITC was excited at $561 \mathrm{~nm}$ and emission collected from 570 to $620 \mathrm{~nm}$. FITC was excited at $488 \mathrm{~nm}$ and emission collected from 500 to $550 \mathrm{~nm}$.
Statistics. For electrophysiological experiments, a single cell was considered an $n=1$. No more than one cell was taken per coverslip and all experiments included cells from at least three different cultures. NR1GFP puncta were visualized from the same cell before and $24 \mathrm{~h}$ after treatment. One to 3 cells were imaged per Petri dish and the mean change in puncta per dish was considered an $n=1$. Data were first tested for normal variance using Bartlett's test; all samples were found to be of equal variance. For datasets with multiple treatments, a two-way ANOVA was performed. If Tat treatment exerted a significant interaction with other treatment groups or if only one treatment (Tat alone) was used, then statistical significance was determined using one-way ANOVA with a Tukey's post hoc test (Prism 5; GraphPad).

\section{Results}

HIV-1 Tat potentiates NMDAR currents that subsequently adapt to baseline during $24 \mathrm{~h}$ exposure

NMDAR signaling in central neurons exposed to the neuroinflammatory HIV-1 protein Tat is potentiated via activation of Src tyrosine kinase (Haughey et al., 2001; Krogh et al., 2014). We previously showed in primary hippocampal cultures treated with Tat $(50 \mathrm{ng} / \mathrm{ml})$ that NMDA-evoked increases in $\left[\mathrm{Ca}^{2+}\right]_{\mathrm{i}}$ were initially potentiated, but then adapted back to baseline by $24 \mathrm{~h}$ (Krogh et al., 2014). Here, we used whole-cell patch-clamp recording to test the effects of Tat on isolated NMDAR currents. Application of $10 \mu \mathrm{M}$ NMDA for 30 s evoked a consistent steadystate current (Fig. 1A). Treatment with Tat for 4 and $16 \mathrm{~h}$ increased the NMDA-evoked current by $24 \pm 5 \%$ and $34 \pm 12 \%$, respectively. The currents adapted back to initial control amplitudes by $24 \mathrm{~h}$ (Fig. $1 A, B$ ). In these experiments, Tat was not 
present in the extracellular solution during recording. Therefore, the effects of Tat persisted for the 1-5 min interval during which the cell culture medium was replaced with recording solution before establishing the whole-cell configuration. Both extrasynaptic and synaptic NMDARs contribute to the steady-state current, so we determined whether NMDAR-mediated synaptic responses exhibited a similar biphasic time course in response to Tat. The NMDAR:AMPAR ratio of evoked EPSCs (eEPSCs) was significantly increased by $73 \pm 11 \%$ after a $4 \mathrm{~h}$ exposure to Tat and adapted to baseline during a $24 \mathrm{~h}$ exposure (Fig. 1C,D). Therefore, somatic and synaptic NMDAR currents are potentiated during exposure to Tat, which then adapt to baseline by $24 \mathrm{~h}$ of exposure.

\section{Potentiation of NMDARs occurs through low-density} lipoprotein receptor-related protein (LRP) receptor signaling Tat is internalized into neurons through the LRP receptor (Liu et al., 2000). The LRP receptor antagonist RAP (50 nM) prevented Tat-induced potentiation of NMDA-evoked increases in $\left[\mathrm{Ca}^{2+}\right]_{\mathrm{i}}$, Tat-induced neuronal death, and Tat-induced loss of synapses (Eugenin et al., 2007; Kim et al., 2008; Krogh et al., 2014). Therefore, we determined whether inhibition of the LRP receptor would prevent the potentiation of the NMDA-evoked current. Treatment with RAP during $4 \mathrm{~h}$ exposure to Tat prevented the potentiation of the NMDA-evoked current. Treatment with RAP alone had no effect (Fig. 2A,B). Therefore, potentiation of NMDARs requires Tat binding to the LRP receptor.

\section{GluN2A-containing NMDARs are necessary for Tat-induced adaptation of NMDAR activity}

The predominant GluN2 subunits of the NMDAR in the hippocampus, GluN2A and GluN2B, are thought to play different roles in regulating synaptic plasticity and neuronal survival (Liu et al., 2007). Therefore, we used subtype-selective antagonists to determine the relative contribution of GluN2A- and GluN2B-containing NMDARs to the adaption of NMDA-evoked current after $24 \mathrm{~h}$ exposure to Tat (Fig. $3 A$ ). Note that NMDAR-mediated currents in Tat-treated cells were comparable to control, consistent with the time course in Figure $1 B$ showing that these currents would have been potentiated and then adapted back to baseline currents. In Xenopus oocytes, 50 nM NVP-AAM007 blocked $>70 \%$ of current through GluN2A-containing NMDARs while sparing GluN2Bcontaining NMDARs (Liu et al., 2004). NVP-AAM007 prevented the adaptation of NMDA-evoked current that occurs during $24 \mathrm{~h}$ exposure to Tat. In the presence of 50 nM NVP-AAM007, treatment with Tat for $24 \mathrm{~h}$ increased the current density by $24 \pm 2 \%$ relative to cells treated with Tat alone, suggesting that adaptation, but not potentiation, requires activation of GluN2A-containing NMDARs. Treatment with NVP-AAM007 alone had no effect on the NMDAevoked current, consistent with effective washout of the drug before recording.

In contrast to blocking GluN2A-containing NMDARs, cotreatment with Tat and ifenprodil $(3 \mu \mathrm{M})$, an antagonist selective for GluN2B-containing NMDARs, did not prevent adaptation of NMDA-evoked current (Fig. 3C). Ifenprodil at a concentration of 3 $\mu \mathrm{M}$ blocked almost $90 \%$ of NMDA-evoked current through GluN2B-containing NMDARs without affecting GluN2A-containing NMDARs (Williams, 1993). Neither ifenprodil nor NVPAAM007 affected the amplitude of the NMDAR current when applied alone, consistent with a previous report (von Engelhardt et al., 2009). To confirm that ifenprodil was not blocking potentiation, which at $24 \mathrm{~h}$ could not be differentiated from failure to block adap-

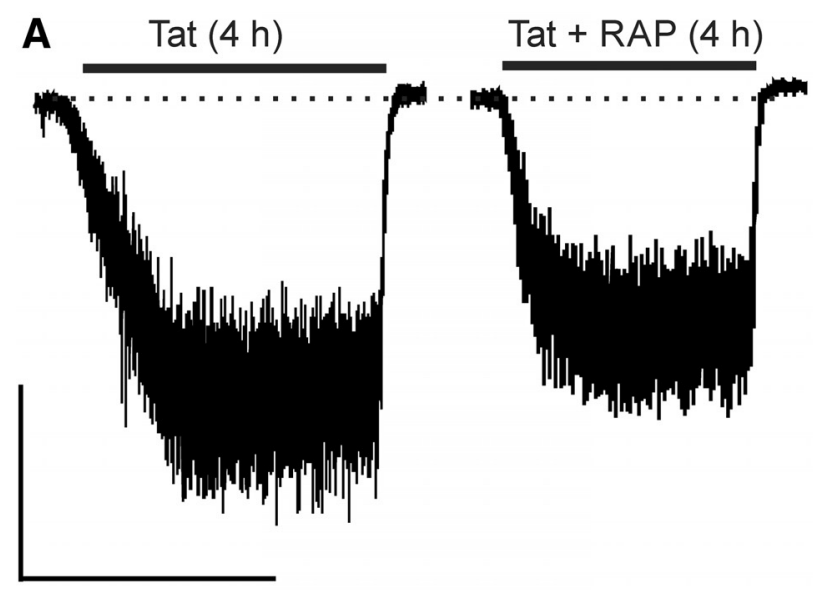

B

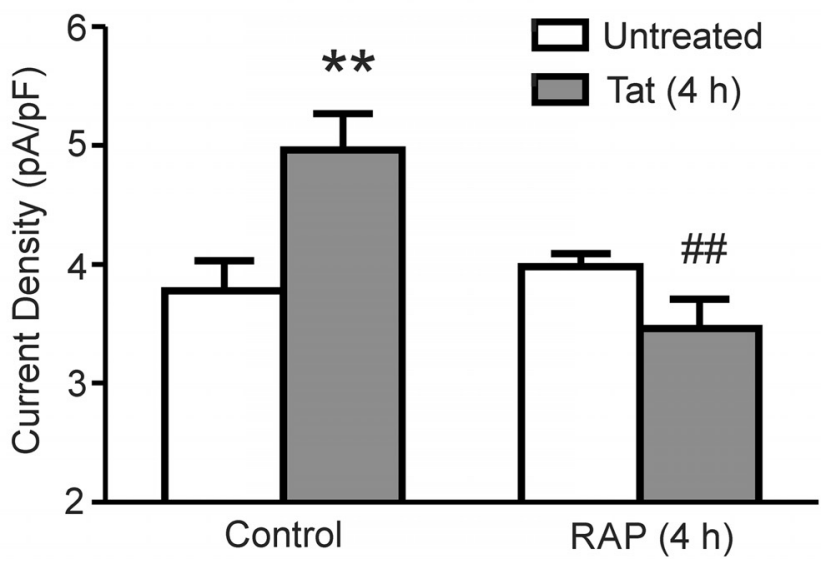

Figure 2. Tat-induced NMDAR potentiation requires LRP. A, Representative traces showing NMDA-evoked steady-state whole-cell current from cells treated with Tat for $4 \mathrm{~h}$ in the absence and presence of RAP $(10 \mu \mathrm{m})$ applied 15 min before Tat. NMDA (10 $\mu \mathrm{m})$ was applied at the time indicated by the horizontal bars. Scale bar, 100 pA, 60 s. $\boldsymbol{B}$, Bar graph summarizing NMDAevoked current normalized to whole-cell capacitance from untreated (open bars) cells or cells treated with Tat (solid bars) for $4 \mathrm{~h}$ in the presence or absence of RAP. Data are shown as mean \pm SEM ( $n \geq 5$ for all groups). ${ }^{* *} p<0.01$ relative to untreated control, \#\#p $<0.01$ relative to Tat + RAP-treated $(4 \mathrm{~h}$ ) (one-way ANOVA with Tukey's post hoc test).

tion, we recorded NMDA-evoked currents after $4 \mathrm{~h}$ treatment with Tat in the presence of ifenprodil. The current density was potentiated by $28 \pm 7 \%$ after $4 \mathrm{~h}$ cotreatment with Tat and ifenprodil, confirming that GluN2B-containing NMDARs were not required for either potentiation or adaptation.

Because the activity of GluN2A-containing NMDARs was selectively driving the adaption of NMDA-evoked currents, we explored the possibility that NMDAR subtypes might selectively potentiate or adapt during exposure to Tat. We tested both NMDA-evoked whole-cell currents and NMDAR-mediated eEPSCs for sensitivity to ifenprodil after different treatment times with Tat. In control cells, ifenprodil inhibited NMDAR-mediated eEPSCs by $60 \pm 2 \%$ and inhibited the NMDA-evoked whole-cell current by $46 \pm 2 \%$. Treatment with Tat for 4 or $24 \mathrm{~h}$ did not change the ifenprodil sensitivity of either the NMDA-evoked whole-cell current or the NMDA eEPSC (Fig. $4 A-D$ ) despite changes in the overall amplitude of the currents (Fig. 1). We interpret these results to mean that Tat-induced potentiation and subsequent adaptation of NMDARs affects both NMDAR subtypes. This is consistent with a previous report of increased phosphorylation of both NMDAR subtypes after exposure to Tat 
(Haughey et al., 2001) and Tat potentiation of NMDA-evoked increases in $\left[\mathrm{Ca}^{2+}\right]_{\mathrm{i}}$ via activation of a Src kinase (Haughey et al., 2001; Krogh et al., 2014). Because Tat appears to exert comparable effects on current amplitudes of both NMDAR subtypes, the selective role of the GluN2A-containing NMDARs in driving adaptation is likely the result of subtype selective coupling to downstream signaling pathways.

\section{Akt-Mdm2 signaling is necessary for downregulation of NMDAR activity} GluN2A-containing NMDARs specifically regulate a neuroprotective Akt signaling pathway (Liu et al., 2007). Because potentiation of NMDARs is neurotoxic (Potter et al., 2013; Nakanishi et al., 2016), adaptation of Tat-potentiated NMDARs might be a neuroprotective response. Therefore, we investigated whether inhibition of Akt would prevent the adaptation of NMDAR currents during $24 \mathrm{~h}$ exposure to Tat. MK-2206 effectively blocks the activation of Akt at a concentration of $1 \mu \mathrm{M}$ (Hirai et al., 2010) and $48 \mathrm{~h}$ of treatment does not cause cell death in primary neuronal cultures (Jewett et al., 2015). MK-2206 prevented the adaptation of NMDA-evoked current that occurs during $24 \mathrm{~h}$ exposure to Tat (Fig. 5A). In the presence of $1 \mu \mathrm{M}$ MK-2206, treatment with Tat for $24 \mathrm{~h}$ increased the current density by $22 \pm 4 \%$ relative to cells treated with Tat alone, suggesting that adaptation, but not potentiation, requires activation of Akt. MK-2206 had no effect on NMDAevoked current by itself.

The E3 ligase, Mdm2 is a known substrate of Akt (Abraham and O'Neill, 2014). Mdm2 ubiquitinates PSD-95, leading to loss of AMPARs (Colledge et al., 2003). It also ubiquitinates p53 to regulate transcription (Abraham and O'Neill, 2014). Here, we used both pharmacological and genetic approaches to determine whether inhibition of $\mathrm{Mdm} 2$ would prevent the adaptation of NMDAR activity during $24 \mathrm{~h}$ of exposure to Tat. Nutlin-3 at a concentration of $1 \mu \mathrm{M}$ selectively inhibits Mdm2 (Vassilev et al., 2004). In the presence of $1 \mu \mathrm{M}$ Nutlin-3, NMDA-evoked currents remained potentiated after $24 \mathrm{~h}$ treatment with Tat (Fig. 5B). Therefore, Akt activation of Mdm2 was responsible for adaptation of NMDARs. Because Mdm2 regulation of NMDARs has not been described previously, we confirmed this result using a genetic approach to target $\mathrm{Mdm} 2$. ARF prevents $\mathrm{Mdm} 2$ regulation of synaptic function and gene expression by binding to $\mathrm{Mdm} 2$ to prevent ubiquitination of its substrates (Zhang et al., 1998). Hippocampal neurons in culture were transfected with expression plasmids for both ARF and GFP or GFP alone and, $48 \mathrm{~h}$ later, they were treated with Tat for an additional $24 \mathrm{~h}$. Cells expressing both ARF and GFP that were treated with Tat for $24 \mathrm{~h}$ displayed significantly larger NMDA-evoked currents than either cells expressing GFP alone that were treated with Tat for $24 \mathrm{~h}$ or cells expressing GFP and ARF without Tat treatment (Fig. 5C). Therefore, 24 h exposure to HIV Tat results in activation of GluN2Acontaining NMDARs with subsequent activation of an Akt and
Mdm2 signaling pathway leading to the adaptation of NMDAR activity.

$\mathrm{Mdm} 2$ is present in synaptic spines and can regulate the local degradation of signaling molecules via the ubiquitin proteasome pathway (Colledge et al., 2003). The action of Mdm2 on p53 regulates transcription (Abraham and O'Neill, 2014). To determine whether Mdm2-dependent adaptation of NMDARs required changes in gene expression, we treated cells with Tat for $24 \mathrm{~h}$ in the absence and presence of anisomycin, an inhibitor of translation. As shown in Figure $5 D, 24 \mathrm{~h}$ of treatment with $10 \mu \mathrm{M}$ anisomycin alone had no effect on NMDA-evoked currents. However, in cultures treated with Tat in the presence of anisomycin, the NMDA-evoked currents failed to adapt. Therefore, Mdm2-mediated adaptation of NMDARs requires regulation of gene expression. The adaptation signaling pathway is shown in Figure $5 E$.

\section{NMDAR clusters are lost after exposure to Tat}

PSD-95 forms a scaffolding complex with NMDARs and regulates their surface expression, localization, and coupling to signaling pathways (Kim and Sheng, 2004; Chen et al., 2015). We have shown previously that $24 \mathrm{~h}$ of exposure to Tat decreases synaptic PSD-95 (Kim et al., 2008). Therefore, we hypothesized that clusters of synaptic NMDARs would be lost after exposure to Tat via activation of $\mathrm{Mdm} 2$. We transfected hippocampal neurons with expression plasmids for the GFP-tagged NMDARsubunit GluNR1 (pCI-EGFP-NR1 wt) and tdTomato (pSyn-tdTomato). Immunocytochemistry was performed on NR1-GFP-expressing cells $72 \mathrm{~h}$ after transfection. GFP- and PSD95-immunoreactive puncta were colocalized. A total of $81 \pm 3 \%$ of GFP puncta colocalized with PSD-95 puncta $(n=4$ Petri 
A

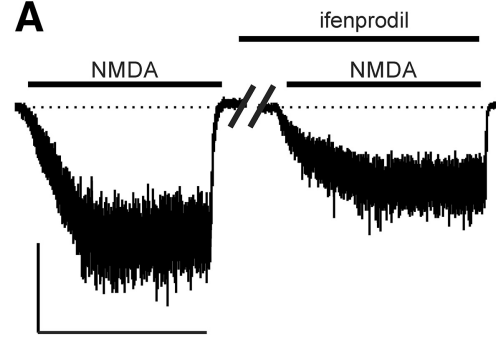

C

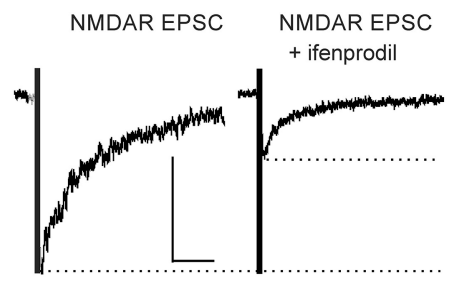

B

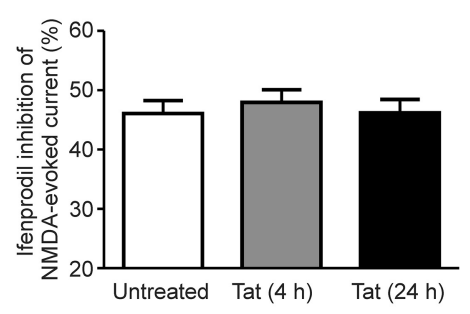

D

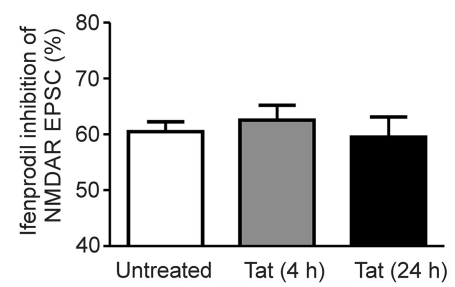

Figure 4. Both subtypes of the NMDAR are potentiated by Tat and adapt during prolonged exposure. $\boldsymbol{A}$, Representative traces showing NMDA-evoked steady-state whole-cell currents before and after $3 \mathrm{~min}$ of perfusion with ifenprodil ( $3 \mu \mathrm{m})$. Drugs were applied as indicated by horizontal bars. Scale bar, 100 pA, 60 s. B, Bar graph summarizing the ifenprodil-induced inhibition of NMDA-evoked steady-state current amplitude after 0 , 4, or $24 \mathrm{~h}$ treatment with Tat. $\boldsymbol{C}$, Representative traces showing evoked NMDA EPSCs from cells voltage clamped at $-70 \mathrm{mV}$ before and after application of ifenprodil. Scale bar, $200 \mathrm{~ms}, 50$ pA. D, Bar graph summarizing the ifenprodil-induced inhibition of NMDA EPSCs after 0, 4, or $24 \mathrm{~h}$ treatment with Tat. Data are shown as mean \pm SEM ( $n \geq 8$ for all groups).

dishes with cells), suggesting that NR1-GFP puncta were located at synapses (Fig. 6A). To determine whether Tat affected the NMDAR clusters, $72 \mathrm{~h}$ after transfection with pSyn-tdTomato and pCI-EGFP-NR1 wt, the cells were imaged $(t=0 \mathrm{~h})$, treated with $50 \mathrm{ng} / \mathrm{ml}$ Tat for $24 \mathrm{~h}$, and then imaged again $(t=24 \mathrm{~h})$. NR1-GFP was expressed in a punctate pattern similar to PSD-95 (Fig. 6A). TdTomato fluorescence was used to define cell morphology and as an indicator of cell health as defined by cytoplasmic retention of the fluorescent protein. NMDAR clusters were counted using an algorithm that counted NR1-GFP fluorescent puncta in contact with a binary mask derived from the red fluorescence image and based on size and intensity criterion (Waataja et al., 2008). After $24 \mathrm{~h}$, puncta were recounted from untreated (control) and Tat-treated cells (Fig. 6C). Average puncta size was $\sim 19 \mu \mathrm{m}^{2}$, consistent with other reports of NR1 puncta size (Wang et al., 2013). Puncta counts in control cells increased by $14 \pm 5 \%$, presumably due to the continued expression of NR1GFP and continued synapse formation in the neuronal culture (Fig. 6D). Exposure to Tat reduced the number of fluorescent puncta by $9 \pm 4 \%$. In cultures treated with Nutlin-3 (1 $\mu \mathrm{M})$, Tat failed to induce loss of NR1-GFP puncta. Nutlin-3 by itself had no effect (Fig. 6D). Therefore, control cells, cells treated with nutlin-3 alone, and cells treated with Tat in the presence of nutlin-3 exhibited comparable puncta counts and were all significantly different from counts derived from Tat-treated cells $(p<$ $0.05)$.

\section{Discussion}

Overactivation of NMDARs contributes to many neurodegenerative disorders including HAND, in which their activity underlies synaptodendritic damage and cell death (Potter et al., 2013). HIV-1 Tat is believed to play a significant role in HAND. It is found in the CSF of HAND patients and antibodies against Tat are neuroprotective (Bachani et al., 2013; Johnson et al., 2013). Furthermore, nanomolar concentrations of Tat cause synapse loss and cell death via activation of NMDARs in in vitro and in

vivo models (Kim et al., 2008; Fitting et al., 2013). Here, we describe changes in NMDAR function during prolonged exposure to Tat. Tat initially potentiated NMDARs via a previously described mechanism involving LRP and Src (Krogh et al., 2014). Our principal finding was that, after Tat-induced potentiation, NMDAR activity was downregulated by a GluN2A-Akt-Mdm2 signaling pathway (Fig. 7). Adaptation of NMDAR activity in the presence of an excitotoxin may be a neuroprotective mechanism to prevent excessive $\mathrm{Ca}^{2+}$ influx.

Tat binds to LRP, forming a complex with NMDARs (Eugenin et al., 2007). Exposure to Tat increases tyrosine phosphorylation of NMDARs (King et al., 2010) and phosphorylation by Src family kinases increases NMDAR channel open probability and mean channel open time (Yu et al., 1997). We found that NMDAevoked whole-cell currents were increased after exposure to Tat and this increase was prevented by inhibition of LRP. The exact role of LRP is unknown, although its ability to internalize bound Tat and its coupling to the mitogen-activated protein kinase pathway may be important (Liu et al., 2000; Geetha et al., 2011). Tat also evokes an inflammatory response in astrocytes and microglia (Nath et al., 1999; Sheng et al., 2000; Zhou et al., 2004; Turchan-Cholewo et al., 2009). Therefore, Tat could potentiate NMDARs indirectly via release of neurotoxic factors such as inflammatory cytokines that activate tyrosine kinases in neurons (Mishra et al., 2012). To investigate the role of synaptic NMDARs, we evoked EPSCs and found that the ratio of NMDAR- to AMPAR-mediated current increased during exposure to Tat, similar to NMDA-evoked whole-cell currents. This is the first report showing enhanced postsynaptic NMDAR currents after exposure to an HIV neurotoxin; this potentiation could trigger the synaptodendritic damage that is the hallmark of HAND.

NMDAR subtypes differentially regulate cell survival and synaptic plasticity (Hardingham and Bading, 2010). GluN2Acontaining NMDARs generally play a neuroprotective role and activation of these receptors promotes cell survival, whereas activation of GluN2B-containing NMDARs promotes cell death (Liu et al., 2007; Martel et al., 2012). These roles depend on context and the stage of development (Paoletti et al., 2013). We found that adaptation of the NMDA-evoked current during exposure to Tat was prevented by inhibition of GluN2A-containing NMDARs, but not by inhibition of GluN2B-containing NMDARs. This observation is consistent with neuroprotective signaling by GluN2A-containing NMDARs because adaptation provides a mechanism to reduce toxic $\mathrm{Ca}^{2+}$ entry via potentiated NMDARs. The selective role for GluN2A-containing NMDARs suggested that Tat might affect only one NMDAR subtype. However, neither the sensitivity of the NMDA-evoked steady-state current nor the sensitivity of synaptically evoked NMDARmediated EPSCs to ifenprodil, an antagonist selective for GluN2B-containing NMDARs, changed after a $4 \mathrm{~h}$ potentiating exposure to Tat, which is consistent with a previous report finding that Tat induced phosphorylation of both GluN2A and 

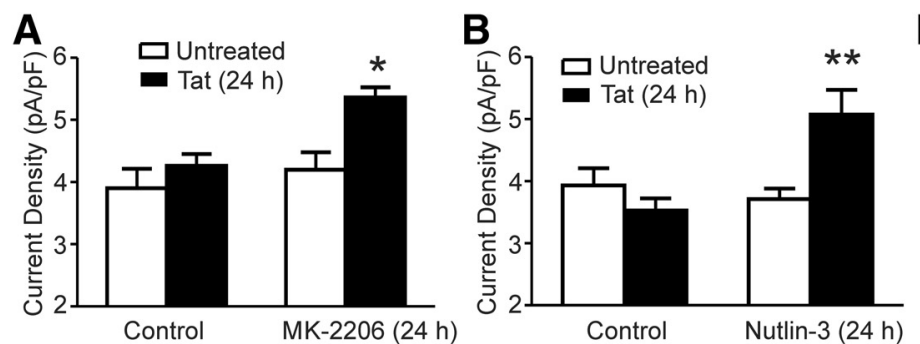

$\mathbf{E}$
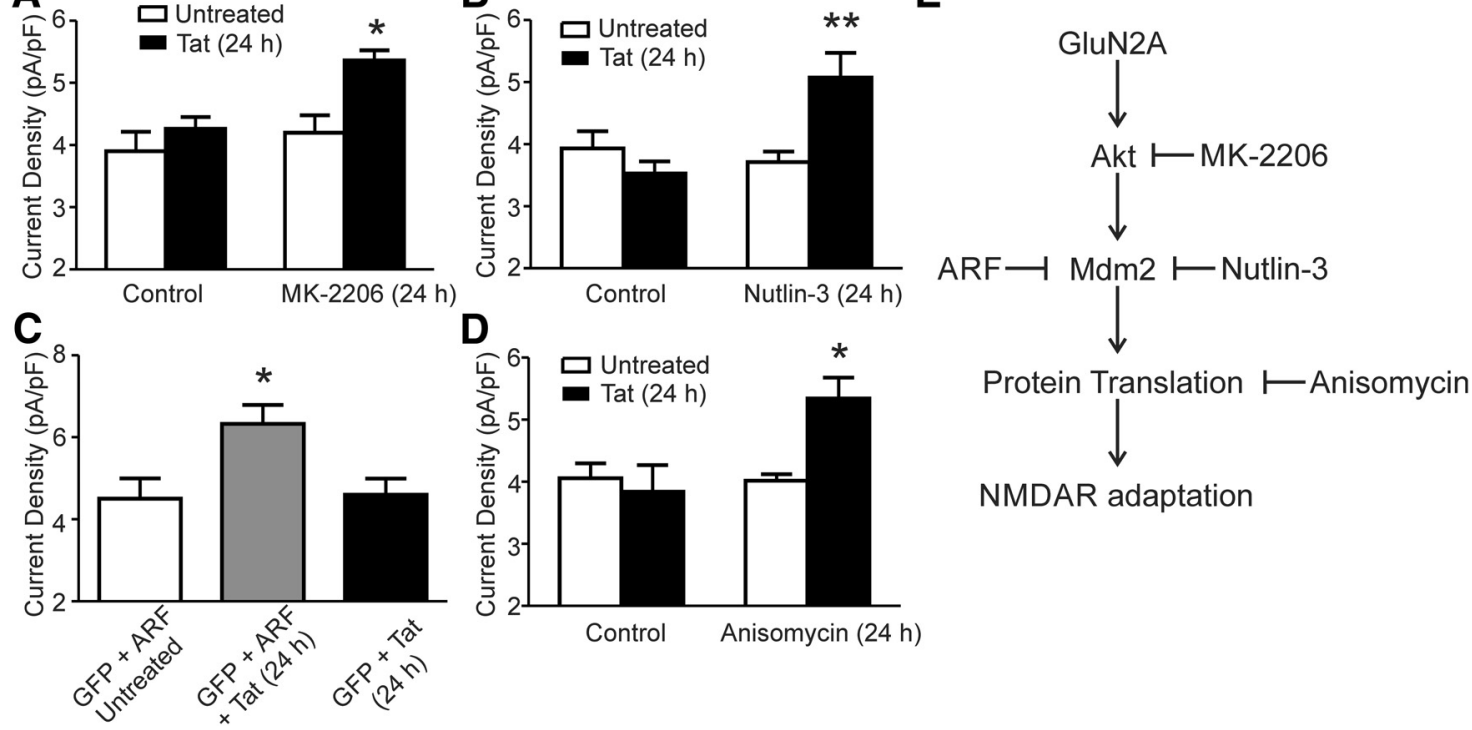

Figure 5. Inhibition of an Akt-Mdm2 signaling pathway prevents NMDAR adaptation to Tat. $\boldsymbol{A}$, Bar graph summarizing the amplitude of NMDA-evoked (10 $\mu$ M NMDA) steady-state currents normalized to whole-cell capacitance from neurons treated with or without Tat for $24 \mathrm{~h}$ in the presence or absence of the Akt inhibitor MK-2206 (1 $\mu \mathrm{M})$. B, Bar graph summarizing the amplitude of NMDA-evoked steady-state currents normalized to whole-cell capacitance from neurons treated with or without Tat for $24 \mathrm{~h}$ in the presence or absence of the Mdm2 inhibitor Nutlin-3 (1 $\mu \mathrm{M}$ ). C, Bar graph summarizing the amplitude of NMDA-evoked steady-state currents normalized to whole-cell capacitance from neurons transfected with GFP and ARF with or without Tat for $24 \mathrm{~h}$ and neurons transfected with GFP alone and treated with Tat for $24 \mathrm{~h}$. D, Bar graph summarizing the amplitude of NMDA-evoked steady-state currents normalized to whole-cell capacitance from neurons treated with or without Tat for $24 \mathrm{~h}$ in the presence or absence of anisomycin $(10 \mu \mathrm{M})$. Data are shown as mean \pm SEM ( $n \geq 6$ for all groups). ${ }^{*} p<0.05,{ }^{* *} p<0.01$ relative to all other groups (one-way ANOVA with Tukey's post hoc test).E, Scheme showing the adaptation pathway activated during $24 \mathrm{~h}$ of exposure to HIV Tat. Signaling elements were identified based on inhibition by the treatments shown.

GluN2B subunits (Haughey et al., 2001). Although the adaptation process was selectively triggered by GluN2A-containing NMDARs, both NMDAR subtypes were downregulated, as indicated by ifenprodil sensitivity after $24 \mathrm{~h}$ of exposure to Tat. Furthermore, GluN2A-containing NMDARs contributed a smaller fraction of the NMDA-evoked current, so their inhibition did not reduce $\mathrm{Ca}^{2+}$ influx to a greater extent than inhibition of GluN2Bcontaining NMDARs. Therefore, activation of GluN2Acontaining NMDARs selectively triggers the adaptation process although potentiation and adaptation appear to affect all NMDAR subtypes similarly. The death-promoting activity of GluN2B-containing NMDARs and the prosurvival activity of GluN2A-containing NMDARs are largely conferred by differences in their intracellular C-terminal domains that enable the receptor subtypes to preferentially couple to different downstream signaling pathways (Martel et al., 2012). Therefore, we examined pathways previously linked to GluN2A-selective signaling as a potential mechanism of adaptation.

The prosurvival activity of NMDARs is mediated by the protein kinase Akt (Yano et al., 1998; Lafon-Cazal et al., 2002), which is selectively activated by GluN2A-containing NMDARs (Liu et al., 2007). Activation of Akt promotes cell survival in animal models of stroke and Alzheimer's disease (Lai et al., 2014; Maiese, 2014). We found that inhibition of Akt prevented adaptation of the NMDA-evoked current after prolonged exposure to HIV-1 Tat. There is precedent suggesting a role for Akt in modulating Tat neurotoxicity as indicated by increased neuronal survival after siRNA knock-down of PTEN (phosphatase and tensin homolog deleted on chromosome 10), a negative regulator of Akt (Zhao et al., 2007). In response to chronic elevation of neuronal activity, an Akt-dependent signaling pathway was shown to attenuate synaptic activity by downregulating AMPARs, but this mechanism has not previously been reported to affect NMDARs
(Jewett et al., 2015). Perhaps overactivation of GluN2Acontaining NMDARs activates a common Akt-dependent pathway to downregulate ionotropic glutamate receptors to restore network homeostasis.

Akt phosphorylates the E3 ubiquitin ligase Mdm2, enhancing its activity (Abraham and O'Neill, 2014). We found that pharmacological or genetic inhibition of Mdm2 blocked adaptation while sparing potentiation, confirming that potentiation and adaptation are mediated by distinct signaling pathways. Regulation of NMDARs by an Akt- and Mdm2-dependent mechanism has not been described previously. Mdm2 ubiquitination of PSD-95 regulates AMPAR function and synaptically mediates long-term depression (Colledge et al., 2003). We have shown previously that Mdm2 mediates Tat-induced synapse loss subsequent to ubiquitination of PSD-95 (Kim et al., 2008). Loss of PSD-95 could underlie adaptation because PSD-95 binds NMDARs and levels of this anchoring protein alter the number, location, and function of NMDARs (Kim and Sheng, 2004; Chen et al., 2015). $\mathrm{Mdm} 2$ also regulates $\mathrm{p} 53$, a regulator of transcription (Abraham and O'Neill, 2014). To test whether Mdm2 exerted its effects via direct ubiquitination and degradation of PSD-95 or through regulation of gene expression, we examined Tat-induced adaption of NMDARs in the presence of anisomycin, an inhibitor of translation. Treatment with anisomycin prevented adaptation of NMDARs after prolonged exposure to Tat. This result does not rule out a role for degradation of PSD-95 in the adaption of NMDARs, although it does suggest that the process is more complex than direct Mdm2 ubiquitination of PSD-95. Recent work has suggested that Mdm2-dependent degradation of p53 can lead to the expression of another E3 ubiquitin ligase, neural precursor cell expressed developmentally downregulated gene 4-like (NEDD4-2), which modifies synaptic function (Jewett et al., 2016). 
A NR1-GFP

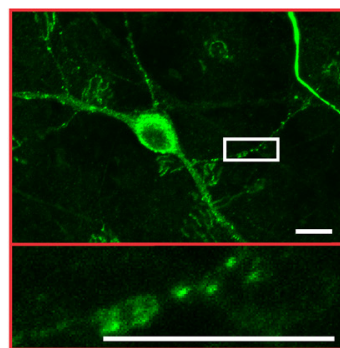

B NR1-GFP

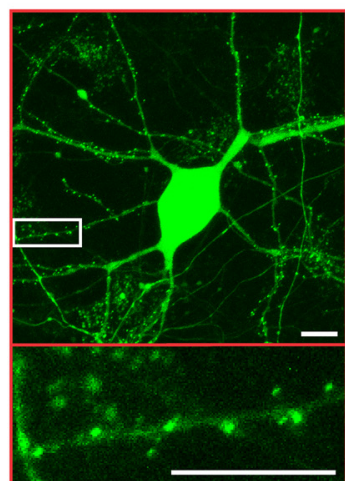

PSD-95

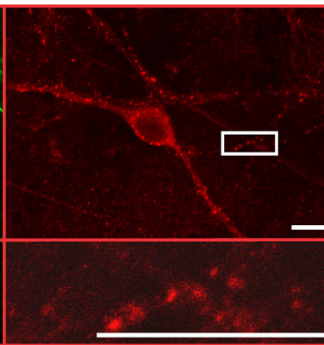

TdTomato

Processed

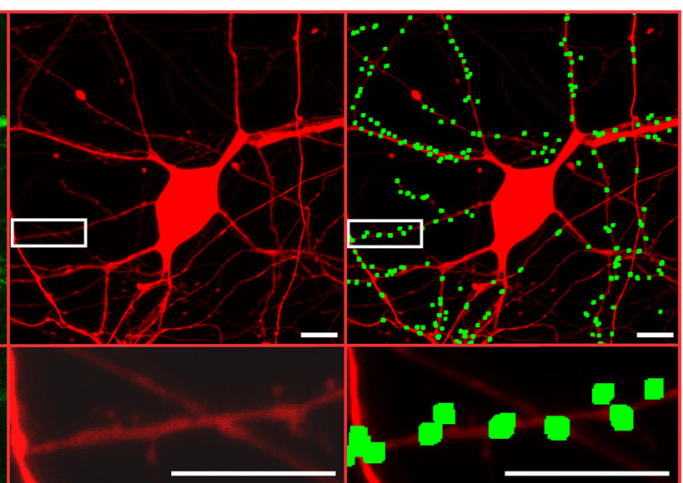

C

Control

Tat

Tat + Nutlin-3

Figure 6. Loss of NMDAR puncta during exposure to Tat is prevented by inhibition of Mdm2. A, Representative images showing a neuron transfected with NR1-GFP and stained with antibodies for GFP (left) and PSD-95 (middle). The merged images (right) show colocalization (yellow). Insets are enlarged regions of boxed images. Scale bars, $10 \mu \mathrm{m} . \boldsymbol{B}$, Representative images showing maximum $z$ projection of a neuron expressing NR1-GFP (left) and tdTomato (middle). After puncta processing (see Materials and Methods), puncta were dilated and overlaid on the tdTomato image (right). C, Representative processed images before $(0 \mathrm{~h})$ and after $(24 \mathrm{~h})$ no treatment (control), treatment with $50 \mathrm{ng} / \mathrm{ml} \mathrm{HIV-1} \mathrm{Tat} \mathrm{(Tat),} \mathrm{or} \mathrm{treatment}$ with Tat $+1 \mu \mathrm{m}$ Nutlin-3. D, Bar graph summarizing the percentage change in NR1-GFP puncta at $24 \mathrm{~h}$ relative to $0 \mathrm{~h}$ images from neurons with or without Tat treatment and in the presence or absence of Nutlin-3 for $24 \mathrm{~h}$. Data are shown as mean \pm SEM ( $n \geq 5$ for all groups). ${ }^{*} p<0.05$ relative to all other groups (one-way ANOVA with Tukey's post hoc test).

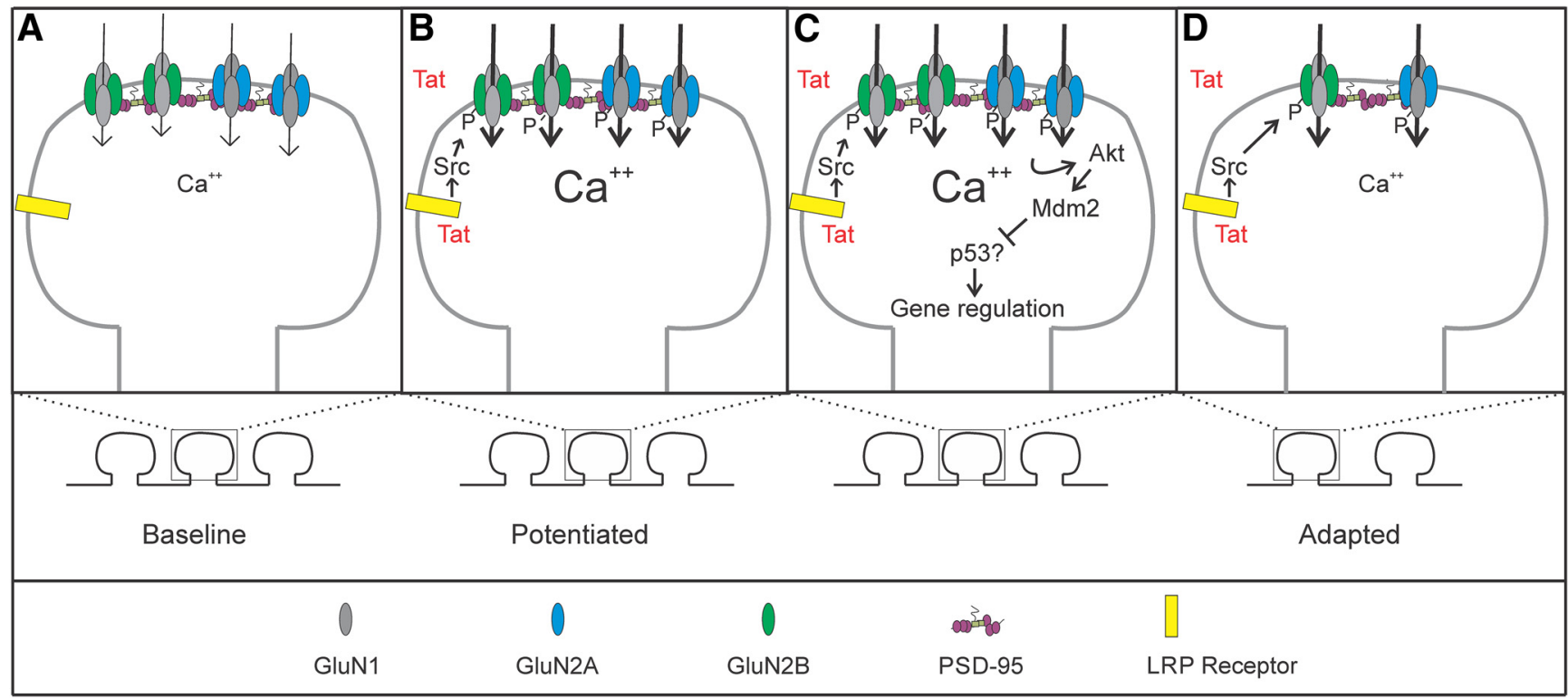

Figure 7. Schematic of signaling events involved in Tat-induced changes in NMDARs. Schematic shows the hypothesized changes in NMDAR function during exposure to HIV-1 Tat. At baseline $(\boldsymbol{A})$, NMDAR-mediated $\mathrm{Ca}^{2+}$ signaling and synaptic number are at homeostasis. After exposure to Tat $(\boldsymbol{B})$, Tat is internalized via the LRP receptor and induces potentiation of $\mathrm{Ca}^{2+}$-influx through NMDARs via a Src-dependent phosphorylation of both GluN2A and GluN2B-containing NMDARs. Prolonged potentiation (C) of GluN2A-containing NMDARs leads to an adapted state via an Akt-Mdm2 signaling pathway that is dependent on protein translation. The adapted state $(\boldsymbol{D})$ contains fewer synapses and $\mathrm{Ca}^{2+}$ influx has adapted in remaining spines. 
Synaptodendritic damage correlates with cognitive decline in patients with HAND (Ellis et al., 2007) and Tat causes synapse loss in both in vitro and in vivo models (Kim et al., 2008; Fitting et al., 2013). In live-cell imaging experiments, NR1-GFP puncta were lost after $24 \mathrm{~h}$ of exposure to Tat, suggesting that adaptation of NMDAR function results in part from the loss of synapses. Indeed, the same signaling components that regulate NMDAR adaptation, GluN2A and $\mathrm{Mdm} 2$, also regulate synapse loss in response to Tat (Kim et al., 2008). Because there is no evidence that Akt or Mdm2 acts directly on NMDAR, it is possible that this pathway controls a coordinated loss of synapses. In models of LTD and homeostatic scaling, Mdm2 activation decreased PSD-95 and GluA1 (Colledge et al., 2003; Jewett et al., 2016). Interestingly, knock-down of PSD-95-like membrane associated guanylate kinases was shown to produce a loss of ionotropic glutamate receptors, followed by consolidation of remaining channels in a reduced number of functional synaptic sites, resulting in normalized quantal size in the remaining synapses (Levy et al., 2015). Perhaps Tat induces a loss of PSD-95 with a subsequent decrease in the number of NMDAR clusters.

Excessive NMDAR-mediated $\mathrm{Ca}^{2+}$ influx is a well established driver of neurotoxicity and adaptation of NMDARs potentiated by the toxin Tat would likely improve neuronal survival. Indeed, inhibition of Mdm2 sensitized neurons to cell death after exposure to Tat (Kim et al., 2008). A challenge to developing neuroprotective agents will be preservation of synaptic function without decreasing long-term neuronal survival. Studies such as this, which delineate the signaling pathways responsible for distinct phases of the neuronal response to neurotoxic insult, will help to identify targets that warrant therapeutic development.

Aberrant regulation of NMDARs by Src family kinases has been described for a number of conditions, including chronic neuroinflammatory pain, intracerebral hemorrhage, and schizophrenia (Sharp et al., 2008; Salter and Pitcher, 2012). Therefore, adaptation of NMDARs via the GluN2A-Akt-Mdm2 pathway described here could prove broadly applicable to many neurological disorders. The homeostatic mechanisms activated during prolonged neurotoxic stress normalize neuronal excitability, but do not necessarily restore the cell to its original state. For example, in this study, NMDAR-mediated currents returned to original whole-cell current densities, but the adapted state had a reduced number of NMDAR synaptic clusters. Future study of the cellular changes that define the adapted state will determine their influence on network function, resilience to insult, and long-term survival.

\section{References}

Abraham AG, O'Neill E (2014) PI3K/Akt-mediated regulation of p53 in cancer. Biochem Soc Trans 42:798-803. CrossRef Medline

Bachani M, Sacktor N, McArthur JC, Nath A, Rumbaugh J (2013) Detection of anti-tat antibodies in CSF of individuals with HIV-associated neurocognitive disorders. J Neurovirol 19:82-88. CrossRef Medline

Carey AN, Sypek EI, Singh HD, Kaufman MJ, McLaughlin JP (2012) Expression of HIV-Tat protein is associated with learning and memory deficits in the mouse. Behav Brain Res 229:48-56. CrossRef Medline

Chen X, Levy JM, Hou A, Winters C, Azzam R, Sousa AA, Leapman RD, Nicoll RA, Reese TS (2015) PSD-95 family MAGUKs are essential for anchoring AMPA and NMDA receptor complexes at the postsynaptic density. Proc Natl Acad Sci U S A 112:E6983-E6992. CrossRef Medline

Colledge M, Snyder EM, Crozier RA, Soderling JA, Jin Y, Langeberg LK, Lu H, Bear MF, Scott JD (2003) Ubiquitination regulates PSD-95 degradation and AMPA receptor surface expression. Neuron 40:595-607. CrossRef Medline

Ellis R, Langford D, Masliah E (2007) HIV and antiretroviral therapy in the brain: neuronal injury and repair. Nat Rev Neurosci 8:33-44. CrossRef Medline
Eugenin EA, King JE, Nath A, Calderon TM, Zukin RS, Bennett MV, Berman JW (2007) HIV-tat induces formation of an LRP-PSD-95- NMDARnNOS complex that promotes apoptosis in neurons and astrocytes. Proc Natl Acad Sci U S A 104:3438-3443. CrossRef Medline

Fitting S, Booze RM, Hasselrot U, Mactutus CF (2006) Intrahippocampal injections of Tat: effects on prepulse inhibition of the auditory startle response in adult male rats. Pharmacol Biochem Behav 84:189-196. CrossRef Medline

Fitting S, Ignatowska-Jankowska BM, Bull C, Skoff RP, Lichtman AH, Wise LE, Fox MA, Su J, Medina AE, Krahe TE, Knapp PE, Guido W, Hauser KF (2013) Synaptic dysfunction in the hippocampus accompanies learning and memory deficits in human immunodeficiency virus type- 1 tat transgenic mice. Biol Psychiatry 73:443-453. CrossRef Medline

Geetha N, Mihaly J, Stockenhuber A, Blasi F, Uhrin P, Binder BR, Freissmuth M, Breuss JM (2011) Signal integration and coincidence detection in the mitogen-activated protein kinase/extracellular signal-regulated kinase (ERK) cascade: concomitant activation of receptor tyrosine kinases and of LRP-1 leads to sustained ERK phosphorylation via down-regulation of dual specificity phosphatases (DUSP1 and -6). J Biol Chem 286:2566325674. CrossRef Medline

Habbas S, Santello M, Becker D, Stubbe H, Zappia G, Liaudet N, Klaus FR, Kollias G, Fontana A, Pryce CR, Suter T, Volterra A (2015) Neuroinflammatory TNFalpha impairs memory via astrocyte signaling. Cell 163: 1730-1741. CrossRef Medline

Hammond ER, Crum RM, Treisman GJ, Mehta SH, Marra CM, Clifford DB, Morgello S, Simpson DM, Gelman BB, Ellis RJ, Grant I, Letendre SL, McArthur JC; CHARTER Group (2014) The cerebrospinal fluid HIV risk score for assessing central nervous system activity in persons with HIV. Am J Epidemiol 180:297-307. CrossRef Medline

Hardingham GE, Bading H (2010) Synaptic versus extrasynaptic NMDA receptor signalling: implications for neurodegenerative disorders. Nat Rev Neurosci 11:682-696. CrossRef Medline

Hargus NJ, Thayer SA (2013) Human immunodeficiency virus-1 tat protein increases the number of inhibitory synapses between hippocampal neurons in culture. J Neurosci 33:17908-17920. CrossRef Medline

Haughey NJ, Nath A, Mattson MP, Slevin JT, Geiger JD (2001) HIV-1 Tat through phosphorylation of NMDA receptors potentiates glutamate excitotoxicity. J Neurochem 78:457-467. CrossRef Medline

Heaton RK et al. (2011) HIV-associated neurocognitive disorders before and during the era of combination antiretroviral therapy: differences in rates, nature, and predictors. J Neurovirol 17:3-16. CrossRef Medline

Hirai H, Sootome H, Nakatsuru Y, Miyama K, Taguchi S, Tsujioka K, Ueno Y, Hatch H, Majumder PK, Pan BS, Kotani H (2010) MK-2206, an allosteric Akt inhibitor, enhances antitumor efficacy by standard chemotherapeutic agents or molecular targeted drugs in vitro and in vivo. Mol Cancer Ther 9:1956-1967. CrossRef Medline

Jewett KA, Zhu J, Tsai NP (2015) The tumor suppressor p53 guides GluA1 homeostasis through Nedd4-2 during chronic elevation of neuronal activity. J Neurochem 135:226-233. CrossRef Medline

Jewett KA, Christian CA, Bacos JT, Lee KY, Zhu J, Tsai NP (2016) Feedback modulation of neural network synchrony and seizure susceptibility by Mdm2-p53-Nedd4-2 signaling. Mol Brain 9:32. CrossRef Medline

Johnson TP, Patel K, Johnson KR, Maric D, Calabresi PA, Hasbun R, Nath A (2013) Induction of IL-17 and nonclassical T-cell activation by HIV-Tat protein. Proc Natl Acad Sci U S A 110:13588-13593. CrossRef Medline

Kim E, Sheng M (2004) PDZ domain proteins of synapses. Nat Rev Neurosci 5:771-781. CrossRef Medline

Kim HJ, Martemyanov KA, Thayer SA (2008) Human immunodeficiency virus protein Tat induces synapse loss via a reversible process that is distinct from cell death. J Neurosci 28:12604-12613. CrossRef Medline

Kim HJ, Shin AH, Thayer SA (2011) Activation of cannabinoid type 2 receptors inhibits HIV-1 envelope glycoprotein gp120-induced synapse loss. Mol Pharmacol 80:357-366. CrossRef Medline

King JE, Eugenin EA, Hazleton JE, Morgello S, Berman JW (2010) Mechanisms of HIV-tat-induced phosphorylation of N-methyl-D-aspartate receptor subunit $2 \mathrm{~A}$ in human primary neurons: implications for neuroAIDS pathogenesis. Am J Pathol 176:2819-2830. CrossRef Medline

Krogh KA, Wydeven N, Wickman K, Thayer SA (2014) HIV-1 protein Tat produces biphasic changes in NMDA-evoked increases in intracellular Ca concentration via activation of Src kinase and nitric oxide signaling pathways. J Neurochem 130:642-656. CrossRef Medline

Krogh KA, Lyddon E, Thayer SA (2015) HIV-1 Tat activates a RhoA signal- 
ing pathway to reduce NMDA-evoked calcium responses in hippocampal neurons via an actin-dependent mechanism. J Neurochem 132:354-366. CrossRef Medline

Lafon-Cazal M, Perez V, Bockaert J, Marin P (2002) Akt mediates the antiapoptotic effect of NMDA but not that induced by potassium depolarization in cultured cerebellar granule cells. Eur J Neurosci 16:575-583. CrossRef Medline

Lai TW, Zhang S, Wang YT (2014) Excitotoxicity and stroke: identifying novel targets for neuroprotection. Prog Neurobiol 115:157-188. CrossRef Medline

Levy JM, Chen X, Reese TS, Nicoll RA (2015) Synaptic Consolidation Normalizes AMPAR Quantal Size following MAGUK Loss. Neuron 87:534548. CrossRef Medline

Liu L, Wong TP, Pozza MF, Lingenhoehl K, Wang Y, Sheng M, Auberson YP, Wang YT (2004) Role of NMDA receptor subtypes in governing the direction of hippocampal synaptic plasticity. Science 304:1021-1024. CrossRef Medline

Liu Y, Jones M, Hingtgen CM, Bu G, Laribee N, Tanzi RE, Moir RD, Nath A, He JJ (2000) Uptake of HIV-1 tat protein mediated by low-density lipoprotein receptor-related protein disrupts the neuronal metabolic balance of the receptor ligands. Nat Med 6:1380-1387. CrossRef Medline

Liu Y, Wong TP, Aarts M, Rooyakkers A, Liu L, Lai TW, Wu DC, Lu J, Tymianski M, Craig AM, Wang YT (2007) NMDA receptor subunits have differential roles in mediating excitotoxic neuronal death both in vitro and in vivo. J Neurosci 27:2846-2857. CrossRef Medline

Maiese K (2014) Taking aim at Alzheimer's disease through the mammalian target of rapamycin. Ann Med 46:587-596. CrossRef Medline

Martel MA, Ryan TJ, Bell KF, Fowler JH, McMahon A, Al-Mubarak B, Komiyama NH, Horsburgh K, Kind PC, Grant SG, Wyllie DJ, Hardingham GE (2012) The subtype of GluN2 C-terminal domain determines the response to excitotoxic insults. Neuron 74:543-556. CrossRef Medline

Mishra A, Kim HJ, Shin AH, Thayer SA (2012) Synapse loss induced by interleukin-1beta requires pre- and post-synaptic mechanisms. J Neuroimmune Pharmacol 7:571-578. CrossRef Medline

Nakanishi N, Kang YJ, Tu S, McKercher SR, Masliah E, Lipton SA (2016) Differential effects of pharmacologic and genetic modulation of NMDA receptor activity on HIV/gp120-induced neuronal damage in an in vivo mouse model. J Mol Neurosci 58:59-65. CrossRef Medline

Nath A, Conant K, Chen P, Scott C, Major EO (1999) Transient exposure to HIV-1 Tat protein results in cytokine production in macrophages and astrocytes. A hit and run phenomenon. J Biol Chem 274:17098-17102. CrossRef Medline

Paoletti P, Bellone C, Zhou Q (2013) NMDA receptor subunit diversity: impact on receptor properties, synaptic plasticity and disease. Nat Rev Neurosci 14:383-400. CrossRef Medline

Potter MC, Figuera-Losada M, Rojas C, Slusher BS (2013) Targeting the glutamatergic system for the treatment of HIV-associated neurocognitive disorders. J Neuroimmune Pharmacol 8:594-607. CrossRef Medline

Salter MW, Pitcher GM (2012) Dysregulated Src upregulation of NMDA receptor activity: a common link in chronic pain and schizophrenia. FEBS J 279:2-11. CrossRef Medline

Saylor D, Dickens AM, Sacktor N, Haughey N, Slusher B, Pletnikov M, Mankowski JL, Brown A, Volsky DJ, McArthur JC (2016) HIVassociated neurocognitive disorder - pathogenesis and prospects for treatment. Nat Rev Neurol 12:234-248. CrossRef Medline
Sharp F, Liu DZ, Zhan X, Ander BP (2008) Intracerebral hemorrhage injury mechanisms: glutamate neurotoxicity, thrombin, and Src. Acta Neurochir Suppl 105:43-46. CrossRef Medline

Sheng WS, Hu S, Hegg CC, Thayer SA, Peterson PK (2000) Activation of human microglial cells by HIV-1 gp41 and Tat proteins. Clin Immunol 96:243-251. CrossRef Medline

Turchan-Cholewo J, Dimayuga FO, Gupta S, Keller JN, Knapp PE, Hauser KF, Bruce-Keller AJ (2009) Morphine and HIV-Tat increase microglialfree radical production and oxidative stress: possible role in cytokine regulation. J Neurochem 108:202-215. CrossRef Medline

Vassilev LT, Vu BT, Graves B, Carvajal D, Podlaski F, Filipovic Z, Kong N, Kammlott U, Lukacs C, Klein C, Fotouhi N, Liu EA (2004) In vivo activation of the 53 pathway by small-molecule antagonists of MDM2. Science 303:844-848. CrossRef Medline

Viviani B, Bartesaghi S, Gardoni F, Vezzani A, Behrens MM, Bartfai T, Binaglia M, Corsini E, Di Luca M, Galli CL, Marinovich M (2003) Interleukin- $1 \mathrm{~b}$ enhances NMDA receptor-mediated intracellular calcium increase through activation of the Src family of kinases. J Neurosci 23: 8692-8700. Medline

Viviani B, Gardoni F, Bartesaghi S, Corsini E, Facchi A, Galli CL, Di Luca M, Marinovich M (2006) Interleukin-1beta released by gp 120 drives neural death through tyrosine phosphorylation and trafficking of NMDA receptors. J Biol Chem 281:30212-30222. CrossRef Medline

von Engelhardt J, Doganci B, Seeburg PH, Monyer H (2009) Synaptic NR2A- but not NR2B-containing NMDA receptors increase with blockade of ionotropic glutamate receptors. Front Mol Neurosci 2:19. CrossRef Medline

Waataja JJ, Kim HJ, Roloff AM, Thayer SA (2008) Excitotoxic loss of postsynaptic sites is distinct temporally and mechanistically from neuronal death. J Neurochem 104:364-375. Medline

Wang X, Lippi G, Carlson DM, Berg DK (2013) Activation of alpha7containing nicotinic receptors on astrocytes triggers AMPA receptor recruitment to glutamatergic synapses. J Neurochem 127:632-643. CrossRef Medline

Williams K (1993) Ifenprodil discriminates subtypes of the N-methyl-Daspartate receptor: selectivity and mechanisms at recombinant heteromeric receptors. Mol Pharmacol 44:851-859. Medline

Yano S, Tokumitsu H, Soderling TR (1998) Calcium promotes cell survival through CaM-K kinase activation of the protein-kinase-B pathway. Nature 396:584-587. CrossRef Medline

Yu XM, Askalan R, Keil GJ 2nd, Salter MW (1997) NMDA channel regulation by channel-associated protein tyrosine kinase Src. Science 275:674678. CrossRef Medline

Zhang Y, Xiong Y, Yarbrough WG (1998) ARF promotes MDM2 degradation and stabilizes p53: ARF-INK4a locus deletion impairs both the $\mathrm{Rb}$ and p53 tumor suppression pathways. Cell 92:725-734. CrossRef Medline

Zhao T, Adams MH, Zou SP, El-Hage N, Hauser KF, Knapp PE (2007) Silencing the PTEN gene is protective against neuronal death induced by human immunodeficiency virus type 1 Tat. J Neurovirol 13:97-106. CrossRef Medline

Zhou BY, Liu Y, Kim Bo, Xiao Y, He JJ (2004) Astrocyte activation and dysfunction and neuron death by HIV-1 Tat expression in astrocytes. Mol Cell Neurosci 27:296-305. CrossRef Medline 